K. Danylkiv, V. Havran, M. Havran, R. Gradzki ${ }^{1}$

Lviv Polytechnic National University

${ }^{1}$ Lodz University of Technology (Lodz, Poland)

\title{
MANAGING THE FINANCES OF WHOLESALE AND RETAIL TRADING ENTERPRISES
}

https://doi.org/10.23939/semi2019.03.081

(C) Danylkiv K., Havran V., Havran M.,. Gradzki R., 2019

The article deals with the main features and trends of financial management development of wholesale and retail trade enterprises. The comparative dynamics of wholesale trade and retail trade in Ukraine and factors that adversely affect the development of enterprises are analyzed. The main stimulating and restraining factors influencing the development of the wholesale and retail market are investigated. Presenting the direct dependence of trade turnover on such macro indicator as GDP and using its projected values by the World Bank for the further years, the authors give the forecast for 2019-2020, and point out a small but positive increase in the turnover of wholesale and retail trading enterprises in Ukraine.

Key words: wholesale trade, retail trade, turnover, dynamics, indicators of the efficiency of enterprises, commodity structure.

Х. П. Данилків, В. Я. Гавран, М. І. Гавран, Р. Грондскі ${ }^{1}$ Національний університет "Львівська політехніка"

1 Лодзинський технологічний університет, (м. Лодзь, Польща)

\section{УПРАВЛІННЯ ФІНАНСАМИ ПІДПРИЕМСТВ ОПТОВОЇ ТА РОЗДРІБНОЇ ТОРГІВЛІ}

\section{() Данилків Х. П., Гавран В. Я., Гавран М. І., Грондскі Р., 2019}

В умовах стрімких змін в економічному та інституційному середовищі комерційної економічної діяльності оновлюється необхідність забезпечення динамічної конкурентоспроможності підприсмств торгівлі. У постійному дисбалансі ринкових умов керівництво торговельних підприсмств потребус достатньої інформації про стан як внутрішніх факторів, так і навколишнього середовища. Актуальність полягає в тому, що зовнішнс середовище функціонування торговельної компанії визначає рівень ії організації та розвитку, що визначає якість торговельних послуг для споживачів, темпи зростання та прискорення товарообігу, прибутковість торгових компаній.

Розкрито теоретичні, методологічні та практичні аспекти вивчення тенденцій розвитку оптових та роздрібних торговельних підприсмств в Україні.

Предметом дослідження с процес становлення та розвитку підприємств оптової та роздрібної торгівлі України та вдосконалення їх фінансового менеджменту.

Ефективне використання заходів щодо поліпшення фінансового менеджменту підприємств торгівлі дасть їм змогу сформувати оптимальну систему ціноутворення, вийти на нові ринки, підвищити задоволеність цільових кліснтів шляхом поліпшення своїх послуг та надання якісних товарів і послуг, підвищення продуктивності та відповідальності персоналу.

За даними Державної служби статистики, у 2018 р. зростання обороту роздрібної торгівлі має позитивну динаміку порівняно 3 попереднім роком, але він змінюється хвилеподібно. Поліпшення було зумовлене розширенням фінансових можливостей 
домогосподарств, підтриманим підвищенням мінімальної заробітної плати та попиту на торговельні послуги підприсмствами реального сектору економіки.

За аналізований період збиткові підприсмства становлять у середньому третину від загальної кількості суб'єктів господарювання. Ця величина с високою і вказує на нездатність підприсмств торгівлі впоратися 3 кризою та забезпечити сталий розвиток.

У 2014-2018 роках спостерігалася тенденція до збільшення роздрібного товарообороту підприємств торгівлі України, а динаміка оптового товарообороту коливалася. Представляючи пряму залежність товарообігу від такого макропоказника, як ВВП, i використовуючи його прогнозовані значення Світовим банком на наступні роки, автори дають прогноз на 2019-2020 рр. підприємств роздрібної торгівлі в Україні.

Ключові слова: оптова торгівля, роздрібна торгівля, товарообіг, динаміка, показники діяльності підприємств, товарна структура.

\section{Statement of the problem}

Today, the economic conditions of commercial business activity in Ukraine are characterized by uncertainty, extreme variability and a high level of riskiness of retail and wholesale trade enterprises activities. In the modern crisis conditions, the issues aimed at searching new means and ways of financial management of trading business require broader research.

An important role in the social and economic development of Ukraine play such economic units as commercial networks, having an opportunity to save on the ranges of activities, distribute resources more effectively, employ more qualified work forces, etc.

Therefore, the relevance of the paper is determined by the need to reveal the development problems of the Ukrainian modern retail and wholesale trading enterprises and to devise the measures aimed at their solution.

\section{Analysis of recent research and publications}

Among a great number of academic economists, who have been researching the issues of financial management, functioning and improving activities of trading enterprises, the following ones should be mentioned: V. Stetsenko [8], P. Kutsyk [5], J. Brovkina [2], O. Dyma [4], O. Deryvedmid [3], I. Balabanova [1], and wholesale and retail trade in particular. They also research the conceptual framework for developing methodological tools for evaluating the functional efficiency and justification of the development strategy of wholesale trade in consumer cooperation; problems and perspectives of developing retail trade; trends of developing trading enterprises. However, the aspects of the management processes and entrepreneurs' operation of financial activities are insufficiently covered. Meanwhile, the significance of the problem is increasing, and practically there is a huge demand for such scientific researches.

\section{The formulation of objectives}

The purpose of the article is to investigate the main tendencies of the financial management of Ukrainian wholesale and retail trade. The study of the theoretical basis and applied problems of diagnostics of the Ukrainian wholesale and retail trade development predetermines the formulation of the following objectives:

, generalize theoretical aspects of researching tendencies towards wholesale and retail trading enterprises development;

, analyze the main financial indicators in comparison with the general number of the wholesale and retail trading enterprises of Ukraine in 2014-2018;

, investigate the key stimulating and deterrent factors influencing the advancement of the wholesale and retail trade market in Ukraine;

, anticipate the Ukrainian wholesale and retail trade market development;

- reveal the core problems of financial management of Ukrainian wholesale and retail trading enterprises and develop effective ways for their deciding. 


\section{Presentation of main materials}

There are some social and economic changes taking place in the process of reforming the Ukrainian economy. They relate to a wide range of activities and branches, in particular, the wholesale and retail trade, where the competitive behavior of certain enterprises is determinative. Trade plays an important role in creating competitive environment, implementing social policy and market orientation of national economy since it is a channel for promoting products to consumers and a kind of economic activity, the object of which is trade exchange and customer services in goods selling, their transportation, storing and preparing for sale.

A financial management of a trading enterprise sets a number of priority tasks, the implementation of which requires the fulfillment of the main functions. Due to the advancement of trading activities and business environment, the financial management functions need to be continuously improved and supplemented. Nowadays, among the functions of financial management of wholesale and retail trading enterprises the most important ones can be distinguished:

- selecting the most effective organizational form of the trading enterprise functioning and its structural units. At the stage of a new trading enterprise creation or expansion, the most effective and applicable organizational and legal form of activity is justified; the most appropriate assortment profile of a store or its separate structural units is determined;

- effective management of technological processes, which involves the selection of the technological scheme of goods movement and appropriate technological equipment; development of the organizational bases for goods supplying, receiving, storing and preparing for sale; determining system of goods placement in the sales area;

- adherence to the principles that meet market requirements, as they have fundamental meaning for building relationships between buyers and sellers in trading;

- focusing on ensuring the efficient and rational financial activity with minimal expenditures under conditions of scarcity of resources, overcoming low-efficiency regulation of trade activity by administrative methods, etc.

Using effective measures aimed at improving financial management of trading enterprises will allow them to form an appropriate pricing system, enter new markets, increase the satisfaction of target customers by improving service activities and providing quality products and services, enhance the working capacity and employees' responsibilities.

The main task of the wholesale trade is to create the most favorable conditions for the subjects of the commodity market in order to implement the rational commodity turnover and, thus, fully satisfy consumers' and retail trading enterprises' demands in the convenient time offering required quantity, quality and assortment of commodities.

The wholesale trade provides:

- organization of the commodity flows and directing them from producers to buyers with minimal turnover costs and maximal speed of the goods movement;

, organization, storage and managing of the stocks of goods, which are necessary for timely support of commodity market entities in case of changing conjuncture;

, ensuring customers' demands in conditions of temporary lack of production or consumption (for example, seasonal breaks in production, transportation by waterways, etc.);

- forming demand for new goods and their promotion to the commodity market.

Retail trade enterprises sell products directly to population, i.e. their function is to completely finish the process of moving goods from a producer to a consumer. To retail goods it is necessary not only to have commercial premises with the conditions for servicing customers properly, but also to form a wide range of goods, systematically change it in accordance with consumers' needs and demands. Thus, we state that the subject of the retail trade is purposed products sale and proper customer services, as well as provision of additional service support. According to the State Statistics Service of Ukraine, the number of retail trading enterprises in Ukraine has started to decrease in the recent years, however, the volume of goods turnover of these enterprises increases every year that indicates an increase in the scope of these entities' activities. 
One of the most important indicators and factors of trade development is the turnover level indicator. According to the State Statistics Service, in 2018, the growth of retail trade turnover had positive dynamics compared with the previous year, but it is changing in a wave-like way (table 1). The improvement was driven by the expansion of households' financial capacity, supported by increasing minimum wages and trade services demand by enterprises in the real sector of the economy.

Table 1

\section{Wholesale and retail trade turnover of wholesale and retail trading enterprises in Ukraine for 2014-2018}

\begin{tabular}{|l|c|c|c|c|c|}
\hline \multicolumn{1}{|c|}{ Indicators } & 2014 & 2015 & 2016 & 2017 & 2018 \\
\hline $\begin{array}{l}\text { Wholesale trade turnover of wholesale } \\
\text { trade enterprises (legal entities), millions } \\
\text { of UAH }\end{array}$ & 987957.0 & 1178887.1 & 1555965.7 & 1908670.6 & 2195695.7 \\
\hline Retail trade turnover', millions of UAH & 901923.7 & 1018778.2 & 1175319.2 & 815344.3 & 928556.4 \\
\hline $\begin{array}{l}\text { Retail trade turnover of retail trade } \\
\text { enterprises (legal entities), millions of } \\
\text { UAH }\end{array}$ & 438342.7 & 477966.6 & 555975.4 & 586330.1 & 667044.3 \\
\hline
\end{tabular}

${ }^{1}$ Excluding the temporarily occupied territory of the Autonomous Republic of Crimea, the city of Sevastopol and a part of the temporarily occupied territories in Donetsk and Luhansk regions.

${ }^{2}$ Includes retail turnover data of enterprises (legal entities and individual entrepreneurs) which main type of economic activity is the retail trade.

Source: developed on the basis of [2, 4, 6, 8].

The main factors of the current dynamics are $[6,8]$ :

Incentive factors:

1. Increasing purchasing power of households due to the minimum wage rise (up to $3723 \mathrm{UAH}$ from January 1, 2018);

2. Improving consumer sentiment of households in the previous year (according to the company GfK in 2018, the consumer sentiment index was 54 p., which is 7.7 p. higher than in 2017);

3. Increased demand for trade services of certain enterprises in the real sector (in the first half-year period of 2018: building activity has increased by $24.6 \%$, process industry - by $8 \%$ ). The improvement of the situation in the industry was in most industrial groups, except for the energy group goods: the output of investment goods has grown by $17.9 \%$, for durable consumer goods - by $12.5 \%$, for short-term consumer goods - by $7.3 \%$, and for intermediate goods - by $1.6 \%$;

4. Growth of imported goods volume (by $28.6 \%$ in 2018; in 2017, the share of imported goods in wholesale trade was $57.7 \%$ (compared to $55.3 \%$ in 2016), while for the retail turnover of enterprises - 46, $9 \%$ (41.3\% in 2016 respectively));

5. High dynamics of lending retail trading enterprises (as of the end of June 2018, compared to the end of June 2017, the volume of loans granted to retail trading enterprises has increased by 1.93). According to the calculations of the Ministry of Economic Development for six-month period of 2017, the ratio of loans granted to retail trading enterprises to the retail trade turnover was 0.39 compared to 0.10 for six-month period of 2016.

Constraint factors:

1. Rising prices at the consumer market (in June 2017 (p/p) CPI (change to the corresponding month of the previous year) was $15.6 \%$, while in June 2016 (p/p) - 6.9\%;

2. Shrinkage of industrial intermediate goods producers' demand on wholesale trade services, first of all, due to obstacles connected with the rail and road transportation of goods across the railways and motorways collision line within Donetsk and Luhansk regions (reducing production by $2.6 \%$ in the first half-year of 2018);

3. Reduction of lending volume of wholesale trading enterprises (at the end of June 2018 comparing to the data at the end of June 2017 , loans granted to wholesale trading enterprises have decreased by 
$25.3 \%)$. On the one hand, it was mostly related to an increase in the profitability level of wholesale trading enterprises (in the first quarter of 2017 the profitability level of operating activities was $41.7 \%$, totally in economy $10.4 \%$ ) and the availability of their own working capital. On the other hand, it was related to tightening of lending standards at corporate business segment (for long-term foreign currency loans and loans to large enterprises). The key factors that have led to more tighten application approval standards were the collateral risks, exchange rate expectations, and bank capitalization reduction.

For the first half-year period time, retail trade turnover has increased in 23 regions (22 regions in January-May 2017 and 18 regions in the first half of 2016). In general, the influence of Donetsk and Luhansk regions on the dynamic of retail trade turnover made up "plus" of 0.2 p.p. (Table 2).

Table 2

The retail trade turnover (regional section), $\% \mathrm{p} / \mathrm{p}$

\begin{tabular}{|c|c|c|c|l|c|c|c|}
\hline \multicolumn{4}{|c|}{ The highest growth rates } & \multicolumn{3}{c|}{ The lowest growth rates and negative results } \\
\hline Region & 2018 & $\begin{array}{c}\text { Share in } \\
\text { structure }\end{array}$ & $\begin{array}{c}\text { Contri- } \\
\text { butions p.p. }\end{array}$ & \multicolumn{1}{|c|}{ Region } & 2018 & $\begin{array}{c}\text { Share in } \\
\text { structure }\end{array}$ & $\begin{array}{c}\text { Contributions } \\
\text { p.p. }\end{array}$ \\
\hline Transcarpathian & 20.9 & 2.1 & 0.5 & Volyn' & -10.3 & 1.6 & -0.4 \\
\hline Vinnytsia & 16.9 & 2.1 & 0.5 & Ternopil & -1.9 & 1.1 & -0.1 \\
\hline Odessa & 13.8 & 8.1 & 0.9 & Chernihiv & 0.3 & 1.7 & -0.02 \\
\hline Sumy & 10.2 & 1.6 & 0.3 & Khmelnitskyi & 0.9 & 1.9 & 0.02 \\
\hline Lviv & 9.2 & 6.2 & 0.5 & Luhansk & 1.3 & 0.6 & 0.01 \\
\hline
\end{tabular}

Source: calculated according to data [6]

For better evaluation of the situation, let us consider the statistical data presented in Table 3.

Table 3

The dynamics of retail and wholesale trading enterprises structure in Ukraine 2014-2018

\begin{tabular}{|l|c|c|c|c|}
\hline \multirow{2}{*}{ Year } & \multicolumn{2}{|c|}{ Wholesale turnover } & \multicolumn{2}{c|}{ Retail turnover } \\
\cline { 2 - 5 } & $\begin{array}{c}\text { share of food } \\
\text { products group, } \\
\%\end{array}$ & $\begin{array}{c}\text { share of non-food product } \\
\text { group, } \%\end{array}$ & $\begin{array}{c}\text { share of food products } \\
\text { group, } \%\end{array}$ & $\begin{array}{c}\text { share of non-food } \\
\text { product group, } \%\end{array}$ \\
\hline 2014 & 20,6 & 79,4 & 40 & 60 \\
\hline 2015 & 19,5 & 80,5 & 39,5 & 60,5 \\
\hline 2016 & 17,6 & 82,4 & 38,9 & 61,1 \\
\hline 2017 & 19,7 & 80,3 & 40,2 & 59,8 \\
\hline 2018 & 18,6 & 81,4 & 41,1 & 58,9 \\
\hline 2018 до 2017 & $-1,1 \%$ & $+1,1 \%$ & $+0,9 \%$ & $-0,9 \%$ \\
\hline
\end{tabular}

Source: calculated according to data [2, 4, 6, 8].

Having analyzed the dynamics of the retail trade turnover structure, we conclude, that the share of food products in the retail trade turnover is increasing, that characterizes the post-crisis situation in the country since the purchasing power of people decreases, and, thus, they invest less in non-food goods.

Considering the structure of the wholesale trade turnover, the opposite situation is observed, i.e. the share of non-food products has increased. It can be explained that wholesale trading enterprises save on transportation costs by purchasing larger consignments of expensive non-food products. Although the turnover of enterprises is increasing, the financial results of trading enterprises are characterized by negative tendencies in the similar periods.

Despite the problems, the development of retail trade networks is considered to be a promising activity. The reports of the Deloitte International Auditing and Consulting Company, which prepares the annual rating of "TOP-500 companies in Central and Eastern Europe", show that according to the 
dynamics of enterprise development and incomes there are six Ukrainian retail trade companies as leaders in the "Retail trade" sub-sector. They are "ATB Market", Fozzy Group, "Epicenter K", "Foxtrot", "Auchan Ukraine", "Furshet". "Foxtrot" is asserted to be a company that lowered the income to $-4.0 \%$ by the previous year, but still manages to hold a leader's position [7]. We present a rating and revenues changes of the six Ukrainian leading companies (Table 4).

Table 4

The rating of Ukrainian trade companies based on the rating of "TOP-500 companies in Central and Eastern Europe-2017"

\begin{tabular}{|c|l|c|c|}
\hline No. & \multicolumn{1}{|c|}{ Company } & $\begin{array}{c}\text { Revenues in 2017 } \\
\text { (millions of EUR) }\end{array}$ & $\begin{array}{c}\text { The change in revenues } \\
\text { compared to 2016 }\end{array}$ \\
\hline 1 & ATB Market & 2,4641 & $26,9 \%$ \\
\hline 2 & Fozzy Group & 2,3906 & $12,0 \%$ \\
\hline 3 & Epicenter K & 1,5542 & $90 \%$ \\
\hline 4 & Foxtrot & 7817 & $-0,4 \%$ \\
\hline 5 & Auchan Ukraine & 4990 & $0,8 \%$ \\
\hline 6 & Furshet & 4948 & $0,0 \%$ \\
\hline
\end{tabular}

Source: calculated according to data [7].

Since the dynamics of Ukraine's retail turnover is determined by the economic growth of the state, so, having the information concerning the forecast of the country's future GDP the volume of the goods turnover can be forecast.

The Figure 1 illustrates the dependence of Ukraine's retail trade turnover on its GDP, which can be expressed by the following regression equation:

$$
\mathrm{Y}=0,836 \mathrm{X}-408517,7
$$

where $\mathrm{Y}$ - retail trade turnover of Ukraine; $\mathrm{X}$ - nominal GDP of Ukraine.

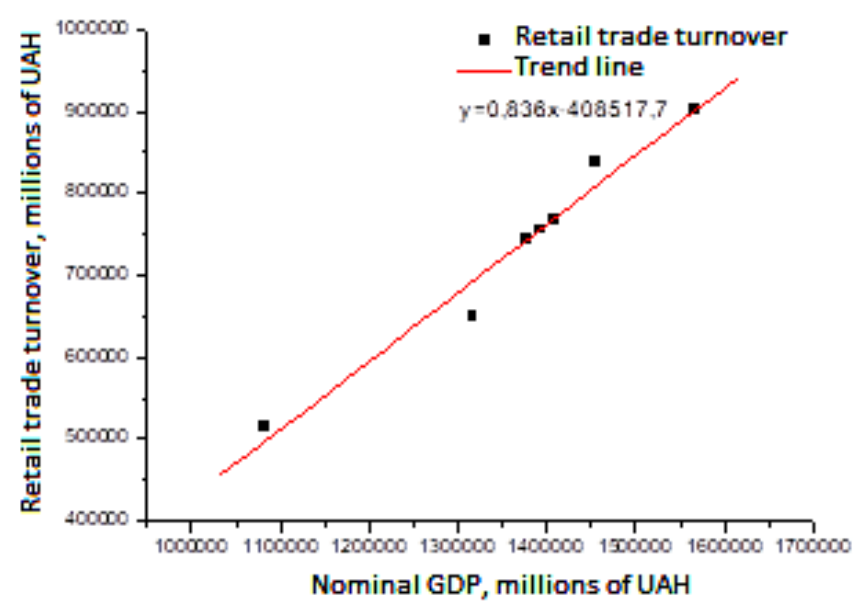

Fig. 1. Correlation of retail trade turnover of Ukraine

with the nominal GDP Source: own analysis based on [2,6]

Thus, using the formula we forecast the country's retail trade turnover:

for 2019: $\mathrm{Y}_{2019}=744092,8$

for 2020: $\mathrm{Y}_{2020}=755618,9$

Therefore, according to the received forecast the dynamics of the trade sector will first of all be determined by the retail trade. The main influencing factors will be the consumer demand by rising real wages and gradual increasing of imported consumer goods supply. In addition, wholesale trade will be characterized by more restrained development dynamics as a result of a temporary transport blockade in the East part of the country that will gradually diminish its influence under diversification conditions of 
sources of raw materials supply to industrial enterprises. The continuing revival of business activity in the economy will be a positive factor (according to the National Bank of Ukraine, in the second quarter of 2019 , for the third quarter in a raw, respondents from all business types are expecting the revival of the business activity for the next 12 months).

Table 5

Problems and prospects of wholesale and retail trading enterprises development

\begin{tabular}{|c|c|c|}
\hline & Problems & Development prospects \\
\hline 1 & $\begin{array}{l}\text { The economic crisis, which has caused inflation and a } \\
\text { high level of hryvnia depreciation, and therefore a huge } \\
\text { increase of dollar exchange rate, that directly affects the } \\
\text { price of goods. }\end{array}$ & \multirow{3}{*}{$\begin{array}{l}\text { An increase in domestic production that } \\
\text { will become possible under the following } \\
\text { conditions: } \\
\text { - providing certain benefits to the } \\
\text { producers by the state; } \\
\text { - minimizing the tax burden, which will be } \\
\text { the first step towards the anti-shadowing of } \\
\text { the wholesale and retail trade sector; } \\
\text { - developing by banks a lending system at } \\
\text { profitable and more loyal interest rates. }\end{array}$} \\
\hline 2 & $\begin{array}{l}\text { Reduction of domestic production of goods, which leads } \\
\text { to imports increase. }\end{array}$ & \\
\hline 3 & $\begin{array}{l}\text { Excessive tax burden, which causes the shadow economy } \\
\text { growth in the trade sector. Increasing of import duty on } \\
\text { non-food products, in particular household appliances and } \\
\text { electronics. }\end{array}$ & \\
\hline 4 & $\begin{array}{l}\text { A large number of ambiguous statements in regulatory and } \\
\text { legal acts on retail and wholesale trade. }\end{array}$ & $\begin{array}{l}\text { More effective and state regulation is } \\
\text { needed. Active involvement of international } \\
\text { experts to cooperation. }\end{array}$ \\
\hline 5 & $\begin{array}{l}\text { Growth of fixed costs: } \\
\text { rent cost; } \\
\text { increase of utilities tariffs; } \\
\text { transportation costs due to fuel costs rising; } \\
\text { indexation of wages and growth of its minimum size, etc. }\end{array}$ & $\begin{array}{l}\text { Involvement of additional funds and } \\
\text { reducing costs: } \\
\text { determine the optimal size of the goods } \\
\text { supply, and their delivering frequency; } \\
\text { - renting out of free premises; } \\
\text { - saving of electricity, transition to more } \\
\text { economical means of heating; } \\
\text { - purchasing more economical cars, as well as } \\
\text { making new, more favorable contracts with } \\
\text { carriers, reducing supply distances; } \\
\text { - redundancy due to improving other } \\
\text { employees' skills. }\end{array}$ \\
\hline 6 & $\begin{array}{l}\text { Accumulation of accounts receivable, which causes the } \\
\text { outflow of funds from the turnover. }\end{array}$ & $\begin{array}{l}\text { Determination of the optimum amount of } \\
\text { receivables, reduction of deadlines, as well } \\
\text { as necessary changes in terms of paying off. }\end{array}$ \\
\hline 7 & Reduction of people's purchasing power. & $\begin{array}{l}\text { Using marketing techniques such as: } \\
\text { - creation of bonuses system for clients; } \\
\text { - holding seasonal and periodic sales, } \\
\text { promotions and discounts; } \\
\text { - selling products that are targeted at } \\
\text { consumers with different income levels. }\end{array}$ \\
\hline 8 & Insufficient level of investment and state support. & $\begin{array}{l}\text { Searching for investors through cooperation } \\
\text { with foreign companies; issuing securities. }\end{array}$ \\
\hline 9 & A large number of counterfeit and poor-quality goods. & $\begin{array}{l}\text { Improved warranty services. Stricter control } \\
\text { over suppliers. }\end{array}$ \\
\hline 10 & $\begin{array}{l}\text { Inability to create an attractive interior and design for } \\
\text { attracting clients. Insufficient staff qualification, low } \\
\text { ethics level for working with buyers. }\end{array}$ & $\begin{array}{l}\text { A number of measures should be } \\
\text { implemented, among them: } \\
\text { - active involvement of foreign specialists } \\
\text { in cooperation and consultations; } \\
\text { - stimulation of staff through providing } \\
\text { benefits and bonuses for a certain amount of } \\
\text { sold goods, made loans, etc. }\end{array}$ \\
\hline
\end{tabular}

Source: developed on the basis of $[1,2,5,8]$. 
Today, the biggest problem for trading enterprises is a significant growth of inflation, which has led to a rapid increase of the foreign currency value, price rising, and lowering consumer purchasing power.

In trading enterprises, the volume of retail turnover are decreasing because of the impossibility to form sufficient commodity stocks due to the suspension of construction projects in all areas and regions of Ukraine and product range reduction, etc. The above-mentioned tendencies directly affect the reduction of trading enterprises' incomes.

A characteristic feature of trading enterprises is an optimization of personnel management costs. There is a redundancy by combining different employees' responsibilities into a single system of effective performance of tasks.

The trading process is characterized by existing technologies that can provide movement of the product (goods) to the final consumer. For retail and wholesale trading enterprises, it is also typical to involve logistics, marketing, standardization systems, certification systems in the trade process, that are able to provide the best quality of goods and trading as well. Operational and sale personnel should, first and foremost, ensure effective and profitable business activities of wholesale and retail trading enterprises. Nowadays, the peculiarity of trading networks is a great experience of national enterprises in managing trading and using world experience especially after a large number of foreign trade operators have entered the consumer market.

One of the problems of retail and wholesale trading enterprises is also a significant lack of resources. Hence, there is a need to determine the optimum amount of resources for the commercial operations of trading companies, as well as to provide alternative channels for their attraction with minimal risks and costs in case of increased additional resource requirements.

With regard to the wholesale trade, the centralized delivery to wholesalers of goods in optimum consignments, range completed with goods from different manufacturers, optimum frequency of delivering, ensures the stability and proper completeness of the product range in retailing. This is especially important for network retailers, whose number in the retail network is significant. In general, due to increasing the size of goods consignments, the costs of transporting and performing other functions related to the goods turnover are reduced. As a result, prices for goods are reducing and the demand for them is increasing. Wholesale intermediaries, important links in logistics systems that should be created in all commodity markets, can contribute to their development in the right way.

\section{Conclusions}

The conducted research allows us to conclude that the modern theory and practice of management requires the creation of new, effective scientific and methodological approaches to assessing the effectiveness of enterprises' financial and economic activities management in all spheres and areas, in particular, in formation and using their financial resources, on the basis of systematic and complex decisions making and their realization.

Under modern conditions, the priority task of business entities is the development and implementation of a balanced system of complex evaluation of the efficiency and performance of financial strategy and financial policy at their formation and implementation stages. In this context, one of the topical tasks is to develop and implement substantiated methodical techniques for a complex evaluation of financial management performance, including retail and wholesale trading enterprises, considering their movement stages and transformation in the process of formation, placement, usage and reproduction at the operational, tactical and strategic levels of enterprise's management activities.

\section{Prospects for future research}

The theoretical research foundations and applied problems of diagnostics of financial management development of the wholesale and retail trade in Ukraine will be used in further research papers. They can deal with complex evaluating of financial management performance at retail and wholesale trading enterprises at the stages of their formation (mobilization), placement (investing), usage and reproduction (return), using a substantiated indicator system based on the surveyed sample of retail and wholesale food products trading enterprises and on the business types of Ukraine. The another prospect for future research 
is determining the criteria and justification of the system of methodical techniques indicators for a complex evaluation of financial management performance at retail and wholesale trading enterprises at different stages of movement and transformation of financial resources, considering the hierarchical levels (operational, tactical, strategic) of the organizational structure of enterprise management.

1. Балабанова Л. В., Митрохіна Ю. П. (2010) Управління збутовою політикою. навч. посіб. для студ. вищ. навч. закл, Донец. нац. ун-т економіки і торгівлі ім. М. Туган- Барановського, Ін-т економіки і упр., Каф. маркетинг. менедж. - Донецьк, 252 с. 2. Бровкіна Ю. О. (2017) Тенденції та перспективи роздрібної торгівлі в Україні, Науковий журнал «Молодий вчений» : Економічні науки. - № 10, 802-806. 3. Дериведмідь О. С. (2011) Аналіз ринку роздрібної торгівлі України, Вісник Запорізького національного університету : Економічні науки. - Вип. 1. - № 1(9). 108-115. 4. Дима О. О. (2015) Роздрібна торгівля в Україні: багатоканальність та додаткові послуги, Вісник Хмельницького національного університету : Економічні науки. - № 1, 221-226. 5. Куцик П. О., Медвідь Л. Г., Шевчук В. О., Харинович-Яворська Д. О. (2015) Діяльність торговельних підприємств у конкурентному середовищі: контрольно-аналітичне забезпечення системи управління [Текст] : монографія. - Чернівці : Технодрук, 370 с. 6. Офіційний сайт Державної служби статистики України Available at : http//www.ukrstat.gov.ua. 7. Рейтинг ТОП-500 компаній Центральної та Східної Свропи Available at: www.deloitte.com. 8. Стеценко В. А., Рябко О. І., Ткачук С. В. (2018) Методи підвищення ефективності роботи роздрібного торговельного підприємства, Електронне наукове видання «Економіка та суспільство». - Вип. № 14, 522-527.

1. Balabanova L. V., Mytrokhina Yu. P. (2010). Upravlinnia zbutovoiu politykoiu [Sale management policy] : Manual. Donets. nats. un-t ekonomiky i torhivli im. M. Tuhan-Baranovskoho, In-t ekonomiky i upr., Kaf. marketynh. menedzh. Donetsk : [DonNUET]. 252 p. 2. Brovkina Yu. O. (2017). Tendentsiyi ta perspektyvy rozdribnoyi torhivli v Ukrayini [Tendencies and perspectives of retail trading in Ukraine]. Naukovyy zhurnal «Molodyy vchenyy» : Ekonomichni nauky. № 10 (50). P. 802-806. 3. Deryvedmid O. S. (2011). Analiz rynku rozdribnoi torhivli Ukrainy [Analysis of retail trade market] Visnyk Zaporizkoho natsionalnoho universytetu : Ekonomichni nauky. Issue 1, № 1(9). P. 108-115. 4. Dyma O. O. (2015). Rozdribna torhivlya v Ukrayini : bahatokanalnist ta dodatkovi posluhy [Retail trading in Ukraine : multi-channel and additional services].Visnyk Khmel'nyts'koho natsional'noho universytetu: Ekonomichni nauky. № 1. P. 221-226. 5. Kutsyk P. O., Medvid L. H., Shevchuk V. O., Kharynovych-Yavorska D. O. (2015). Diyalnist torhovelnykh pidpryyemstv u konkurentnomu seredovyshchi: kontrolno-analitychne zabezpechennya systemy upravlinnya [Tekst] : Monograph. Chernivtsi : Tekhnodruk. 370 p. 6. Ofitsiinyi sait Derzhavnoi sluzhby statystyky Ukrainy [Educational site of State Statistics Service of Ukraine]. Retrieved from : http//www.ukrstat.gov.ua/ 7. Reitynh TOP-500 kompanii Tsentralnoi ta Skhidnoi Yevropy [Rating of TOP-500 companies in Central and Eastern Europe] Retrieved from: www.deloitte.com 8. Stetsenko V. A., Ryabko O. I., Tkachuk S. V. (2018). Metody pidvyshchennya efektyvnosti roboty rozdribnoho torhovelnoho pidpryyemstva [Methods of improving efficiency of retail trading enterprise's work]. Elektronne naukove vydannya «Ekonomika ta suspilstvo». Issue 14. 522-527. 